\title{
Features of cadastral accounting and monitoring of water facilities in Ukraine
}

\author{
Olga Petrakovska ${ }^{1}$, Marharyta Dubnytska² \\ Kyiv National University of Construction and Architecture \\ Povitroflotsky avenue 31, Kyiv, Ukraine, 03037 \\ 1.petrakovskaolga@gmail.com, orcid.org/0000-0002-9437-9730 \\ 2dubnytskamv@gmail.com, orcid.org/0000-0002-1907-1496
}

The manuscript was received on 06.10.2017 and was accepted after revision for publication on 05.02.2018

DOI: 10.31493/tit1811.0103

\begin{abstract}
Presents the peculiarities and problems of water bodies cadastral account in Ukraine. The results of analyses the regulatory framework in the field of water bodies monitoring and account in cadastre are presented. Authors compare approaches to the water objects classification of Ukrainian and European legislation and the science of hydrology. The article presents a consolidated list of types of water bodies with definitions in terms of cadastre. Authors consider objects classification of the cadastral systems according to their dimension, that is, the ability to simulate the real world object in a certain amount of spatialtemporal measurements.

The system of water management authorities in Ukraine and distribution of responsibilities between them are also analyzed. Authors identified some problems such as mutual duplication of functions, and sometimes even conflicts over the division of powers between different executive bodies. The system of water objects state registration in Ukraine according to the current legislation is formalized. In particular, the systems for water objects account in Ukraine are analyzed in detail.

Authors have sent information requests for public information to the authorities, that manage State Water Cadastre in Ukraine (the State Agency of Water Resources of Ukraine, the State Service of Ukraine for Emergency Situations, the State Service of Geology and Subsoil of Ukraine). On the basis of responses analysis the status of State Water Cadastre in Ukraine is investigated and its ability to carry out managerial tasks is evaluated. It is proved that water bodies account in existing twodimensional cadastral systems in principle cannot
\end{abstract}

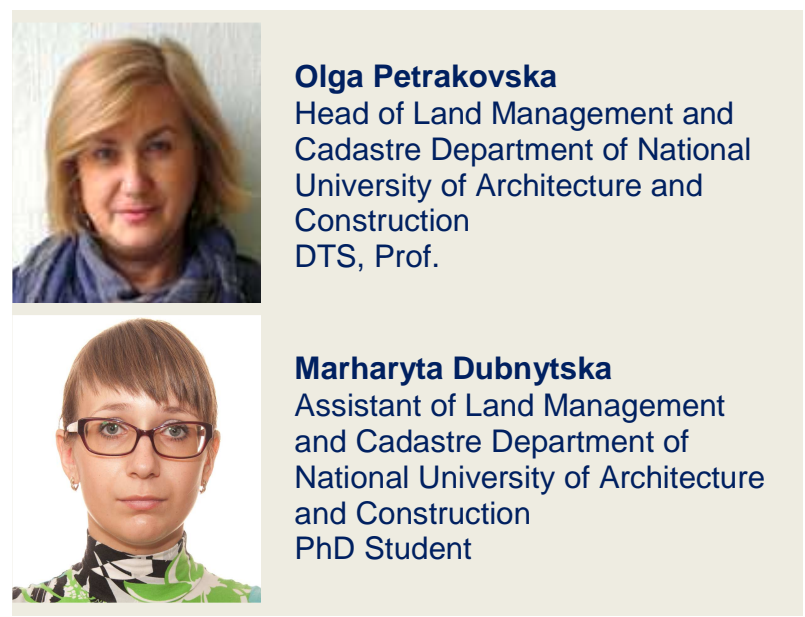

be complete and adequate, as water objects are three-dimensional in nature. Finally, authors recommend to develop a single, three-dimensional monitoring and account system for water objects in Ukraine.

Keywords: water bodies, managerial decisions, 3D cadastre, classification, State Water Cadastre.

\section{INTRODUCTION}

Water objects are strategically important for the development and life of society. According to the definition of the UN Economic Commission for Europe, the state, whose water resources do not exceed 1,5 thousand cubic meters per capita, is not sufficiently provided with water. In Ukraine, the specific value of 
local runoff in a shallow water year per capita is 0,52 thousand cubic meters, and taking into account the transit flow $-1,02$ thousand cubic meters [1]. The level of supply of fresh river runoff in Ukraine is almost 6 times less than the world's figures (6.2 thousand cubic meters per person), therefore and so it is one of the the least provided by water resources country in. In view of this, it is extremely important that water resources are properly accounted for and managed effectively.

The purpose of the study is to determine the peculiarities of cadastral accounting of water objects in Ukraine, as well as to analyze the regulatory framework in the field of monitoring and cadastral accounting of water bodies in order to assess the actual state of water objects. Achieving the goal requires solving the following tasks:

- comparison of existing approaches to the water bodies classification of in Ukraine;

- definition of cadastral systems types in which water objects can be recorded;

- analysis of the water objects state management system in Ukraine;

- analysis of the water objects state registration system in Ukraine (in accordance with the current legislation);

- submission of information requests to the State Water Cadastre administration authorities and analysis of received answers to determine the actual state of water objects registration in Ukraine;

- substantiation of the necessity of keeping records about water objects in the $3 \mathrm{D}$ cadastre by means of analyzing the administrative issues which require three-dimensional information.

\section{RESEARCH PRESENTATION}

According to the Water Code of Ukraine, a water object is a natural or artificially created element of the environment in which water is concentrated. The current legislation of Ukraine defines such water objects as sea, estuary, river, stream, lake, reservoir, pond, canal, and aquifer. [2, art.1] All of them will be further discussed in more detail.
The sea as a water object includes the territorial sea of Ukraine, which consists of coastal sea waters of 12 nautical miles in width, and inland waters of Ukraine, including seawater, located to the shore from the lines of the territorial sea of Ukraine width reference, the water of ports, as well as bays, lions and estuaries, harbors and raids, whose banks are wholly owned by Ukraine [3]. Estuary is not genetically a part of the sea, but is the mouth of the river valley or beam, flooded with sea waters [2, art.1].

There is no definition of the term "river" in the Ukrainian legislation. At the same time, V.K. Khilchevsky and O.G. Obodovsky give the following interpretation: "The river is called the water stream (watercourse), that flows in the natural course and is fed by the waters of the surface and underground drains of its basin. The rivers include only permanent and relatively large watercourses with drainage basin area of not less than 50 square $\mathrm{km}$. Small rivers with drainage basin area up to 50 square $\mathrm{km}$ are called streams" [4]. European Parliament and Council Directive 2000/60/EC of the of 23 October 2000 on the Community's water policy framework establishment (hereinafter referred to as the Water Framework Directive), which is the main regulatory document for Ukraine-European relations in the field of water policy, defines the river as an array of inland water. This Directive defines the river as an array of inland water, which proceeds mainly on the surface of the earth, but may part of its path to proceed underground [5]. In our opinion, the definition is very important for urban areas were the underground rivers are often going into concrete collectors and they actually transform into a part of city sewage. [6] Recognition of such artificially modified rivers as water objects allows us to create a proper legal field for their protection [Annals].

Depending on the area of the drainage basin (parts of the earth's surface and thicker soils, from which water flows into the drainage or reservoir) [2, art.1], rivers in Ukraine are divided into large ones with drainage basin area of more than 50 thousand square $\mathrm{km}$, medium (from 2 to 50 thousand square $\mathrm{km}$ ) and small 
(up to 2 thousand square $\mathrm{km}$ ) [2, art.79]. In accordance to this classification, and to individual land management projects, coastal protective zones are set along the river on, 100, 50 and $25 \mathrm{~m}$ in, respectively [2, art.88].

The European typology of rivers is significantly different from the Ukrainian ones. Depending on the drainage basin area rivers are defined:(from 10 to 100 sq. $\mathrm{km}$ ), medium (from >100 to 1000 sq. km), large (from $>1000$ to 10000 sq. $\mathrm{km})$ and very large (>10 000 sq. km) r [5]. Such a situation causes some difficulties during the European Union international legal acts implementation in Ukraine.

Part of the river bed can be converted into a reservoir - an artificial water object with a capacity of more than 1 million cubic meters, built to create a water reserve and regulate its flow. An artificial reservoir, the capacity of which does not exceed 1 million cubic meters, is called the pond [2, art.1]. From a hydrological point of view, reservoirs occupy an intermediate position between rivers and lakes. The size of the coastal protective zone along the pond or reservoir depends on the area its surface: $25 \mathrm{~m}$ for ponds with an area of less than Among lakes of anthropogenic origin, a separate place is occupied by technological reservoirs - artificially created reservoirs of special technological purpose determined by a technical project and / or passport, which are filled artificially with the help of hydraulic structures and devices [2, art.1]. Often, technological reservoirs are intended for the purpose of fishing or industry.

3 hectares, $50 \mathrm{~m}$ - for reservoirs on medium-sized rivers and ponds with an area of more than 3 hectares, $100 \mathrm{~m}$ - for reservoirs on large rivers [2, art.1].

The channel, or above-ground water pipeline, is a hydrotechnical structure in the form of an open artificial channel with an unpunched flow of water [7]. By appointment distinguish navigable, energy (derivative), irrigation, watering, plumbing, drainage, timber, fish channels, as well as channels of complex destination [8]. According to Ukrainian legislation, navigation channels have a special status and relate to transport lands, while the remaining channels belong to water fund lands [9, art.58, 69, 70; 10, art.28].

While reservoirs and ponds are intended to redistribute water resources in time, channels and conduits provide such redistribution in space [4].

As for the lakes, the European and Ukrainian definitions practically coincide. According to the Water Code of Ukraine, the lake is a natural basin of land filled with fresh or salty waters [2, art.1] and the Water Framework Directive defines it as an array of standing internal surface water [5, art.1]. There is no classification of lakes at the legislative level in Ukraine, and the European community distinguishes lakes depending on the depth (up to 3 $\mathrm{m}$, from 3 to $15 \mathrm{~m}$ and more than $15 \mathrm{~m}$ ) and surface area (from 0,5 to $1 \mathrm{sq}$. $\mathrm{km}$; from 1 to 10 sq. km, 10 to 100 sq. km, over 100 sq. km) [5]. At the same time, the genetic classification of lakes is widespread among the hydrologists, who differentiates lakes, depending on the origin of their basin, and divides they into tectonic, volcanic, exogenous, karst, sulphosus, eolian and anthropogenic ones [4].

The lack of a legally defined classification of lakes leads to uncertainty in the size of their coastal protective zones. In practice, in the course of development land management or spatial planning projects, an analogy of the law with respect to ponds is used. But sometimes in such cases lakes are neglected, especially in settlements [11].

The last type of water objects according to the Water Code of Ukraine is the aquifer - a homogeneous stratum of rocks, where water is constantly located [2, art.1]. An identical term in the Water Framework Directive is determined as a subsurface layer or layers of rocks or other geological breeds of sufficient porosity and permeability in order to make it possible either a significant flow of groundwater or the removal of significant amounts of groundwater (any water below the soil surface in the saturation zone and in direct contact with the soil or substrate) [5]. The outcrops of aquifers on the earth's surface are called sources, but this definition is not in the legislative field. In order to protect the aquifers from pollution, the sanitary protection zones are established 
around sources of underground water supply on the basis of land management projects [2, art.113]. These zones are divided into three stripes of special regime (the first one is strict mode, the second is restrictions, the third one is observation), the size of which depends on the source protection degree, the microbial and chemical pollution risk, the characteristics of sanitary, hydrogeological and hydrological conditions [12].

Hydrology, the science of the water shell of the globe (the hydrosphere), allocates another water object - swamps - excessively moistened land with a stagnant water regime and a specific vegetation. Water in the swamps is stagnant or weakly convex, which causes the accumulation of organic matter in them in the form of peat. Swamps help to regulate the flow of rivers, clean up atmospheric air from excess carbon dioxide, and their destruction can lead to deterioration of water balance in the whole region [4]. On 29 May 1995, the European Parliament and the Council adopted a communication on the rational use and conservation of highly humid lands, which recognized the important functions they perform in the protection of water resources. In view of the significant role of swamps in preserving waters and regulating their volume, in our opinion, the list of water bodies, as defined in the Water Code of Ukraine, should be supplemented by including swamps in it. It is also necessary at the legislative level to regulate the protection of swamps, their economic use and the account of them.

At the same time, fundamentally different classification features of water objects form the basis of domestic and European legislative and hydrological classification. Such situation complicates, on the one hand, the process of these objects account, and on the other hand the introduction of scientific advances. Thus, the Water Code of Ukraine, conditionally divides water bodies, depending on the location and origin of them, into three groups: surface water; groundwater and springs; inland seawater and territorial sea. In turn, surface water includes natural watercourses (rivers, streams), natural reservoirs (lakes), artificial reservoirs (reservoirs, ponds) and watercourses (chan- nels), as well as other water objects [2]. The basis of the hydrological water bodies classification is their water regime specificity, that is, the logical changes in their state in time. Accordingly, the hydrologists distinguish three types of water bodies: water streams in which water moves along the ground surface in a forward direction (rivers, streams and channels), reservoirs with slow water motion (oceans, seas, lakes, ponds, reservoirs and marshes), and special water objects - underground waters and glaciers [4]. The EU Water Framework Directive is based on the water massifs internal homogeneity degree, distinguishing groundwater and surface water, including rivers, lakes, transitional waters and coastal waters [5] (Table 1).

Table 1. Comparison of approaches to the water objects classification

\begin{tabular}{|c|c|c|}
\hline \multicolumn{2}{|c|}{ Ukrainian classification } & \multirow{2}{*}{$\begin{array}{c}\text { European } \\
\text { classifica- } \\
\text { tion [5] }\end{array}$} \\
\hline $\begin{array}{c}\text { Legislative } \\
{[2,4]}\end{array}$ & Scientific [4] & \\
\hline \multicolumn{3}{|c|}{ Classification attributes of water objects } \\
\hline $\begin{array}{l}\text { water objects } \\
\text { location and } \\
\text { origin }\end{array}$ & $\begin{array}{l}\text { water regime } \\
\text { specificity }\end{array}$ & $\begin{array}{l}\text { water mas- } \\
\text { sifs internal } \\
\text { homogene- } \\
\text { ity degree }\end{array}$ \\
\hline $\begin{array}{l}\text { Surface water: } \\
\text { • natural } \\
\text { watercourses } \\
\text { (rivers, } \\
\text { streams) } \\
\text { • natural } \\
\text { reservoirs } \\
\text { (lakes) } \\
\text { • artificial } \\
\text { reservoirs } \\
\text { (reservoirs, } \\
\text { ponds) and } \\
\text { watercourses } \\
\text { (channels) } \\
\text { • other wa- } \\
\text { ter objects } \\
\text { Groundwater } \\
\text { and springs } \\
\text { Inland sea- } \\
\text { water and } \\
\text { territorial sea }\end{array}$ & $\begin{array}{l}\text { Water streams } \\
\text { - rivers } \\
\text { - streams } \\
\text { • channels } \\
\text { Reservoirs } \\
\text { - oceans } \\
\text { - seas } \\
\text { - lakes } \\
\text { - ponds } \\
\text { - reservoirs } \\
\text { - marshes } \\
\text { Special water } \\
\text { objects } \\
\text { - underground } \\
\text { waters } \\
\text { - glaciers }\end{array}$ & $\begin{array}{l}\text { Surface } \\
\bullet \text { water } \\
\bullet \text { rivers } \\
\bullet \text { lakes } \\
\text { - transi- } \\
\text { tional wa- } \\
\text { ters } \\
\bullet \text { coastal } \\
\text { waters } \\
\text { Groundwa- } \\
\text { ter }\end{array}$ \\
\hline
\end{tabular}


The instrument of a particular object or resource accounting and monitoring is a cadastre - an information system used in the process of managing this object or resource at the local or state level. This system is as a basis for decision making in the issues of use and protection of various water bodies. Most traditional cadastral systems contain metric and semantic information about accounting objects.

One of the characteristics of the cadastral system is its dimension, that is, the ability to simulate the real world object in a certain amount of spatio-temporal measurements. In almost all existing cadastres, the accounting units boundaries are presented in the form of their projections on the contingent level, respectively, the cadastral metric is described in two dimensions (2D cadastre) [13]. The concept of 2,5D [13] cadastre takes the intermediate position between two and threedimensional cadastres. In this case, the account units projections may be different from the zero value relative to the conditional level surface. And although the 2,5D cadastre allows to set the rights in volume, it is not able to simulate real 3D surfaces. 3D cadastre, operating on three-dimensional bulk geodata, describes, on the one hand, volumetric physical objects (as close as possible to the real world mathematical modeling method), and on the other hand - a legal 3D space, which includes rights and duties of third parties in relation to the accounting object, as well as restrictions on its use [14]. In the full 3D cadastre, threedimensional space is represented in the form of volumes, without overlays and spaces [13, 14]. But such a system has not yet been fully implemented in any country in the world.

Since the cadastre is, first and foremost, an instrument of public administration, the bodies of state executive power and local selfgovernment formulate the tasks for designingand specific consumer requirements to the cadastral system in the process of its development.

Today, the state water objects management in Ukraine independently carry out ten bodies of executive power subordinated to six ministries, as well as local administrations and local government bodies (Table 2).
Table 2. The system of water management authorities in Ukraine

\begin{tabular}{|l|l|}
\hline \multicolumn{1}{|c|}{$\begin{array}{c}\text { The profile } \\
\text { ministry }\end{array}$} & The body of executive power \\
\hline \multirow{4}{*}{$\begin{array}{l}\text { Ministry } \\
\text { of Agrarian Pol- } \\
\text { icy and Food of } \\
\text { Ukraine }\end{array}$} & $\begin{array}{l}\text { State Service of Ukraine on } \\
\text { Geodesy, Cartography and } \\
\text { Cadastre }\end{array}$ \\
\cline { 2 - 2 } & $\begin{array}{l}\text { State Agency of Fisheries of } \\
\text { Ukraine }\end{array}$ \\
\cline { 2 - 2 } $\begin{array}{l}\text { State Service of Ukraine for } \\
\text { Food Safety and Consumer } \\
\text { Protection }\end{array}$ \\
\hline $\begin{array}{l}\text { Ministry } \\
\text { of Internal Af- } \\
\text { fairs of Ukraine }\end{array}$ & $\begin{array}{l}\text { State Service of Ukraine for } \\
\text { Emergency Situations }\end{array}$ \\
\hline \multirow{2}{*}{$\begin{array}{l}\text { Ministry } \\
\text { of Ecology and } \\
\text { Natural Re- } \\
\text { sources of }\end{array}$} & $\begin{array}{l}\text { State Agency of Water Re- } \\
\text { sources of Ukraine }\end{array}$ \\
\cline { 2 - 2 } Ukraine & $\begin{array}{l}\text { State Service of Geology and } \\
\text { Subsoil of Ukraine }\end{array}$ \\
\cline { 2 - 2 } & $\begin{array}{l}\text { State Ecological Inspection } \\
\text { of Ukraine }\end{array}$ \\
\hline \multirow{3}{*}{$\begin{array}{l}\text { Ministry of In- } \\
\text { frastructure of }\end{array}$} & $\begin{array}{l}\text { Department of Urban Devel- } \\
\text { opment, Architecture and } \\
\text { Territory Planning }\end{array}$ \\
\cline { 2 - 2 } $\begin{array}{l}\text { Territory improvement and } \\
\text { utilities management }\end{array}$ \\
\cline { 2 - 2 } $\begin{array}{l}\text { Department for the reforma- } \\
\text { tion and operation of sea and } \\
\text { river transport }\end{array}$ \\
\hline $\begin{array}{l}\text { Ministry of En- } \\
\text { ergy and Coal } \\
\text { Industry of } \\
\text { Ukraine }\end{array}$ & $\begin{array}{l}\text { Ministry of Energy and Coal } \\
\text { Industry of Ukraine }\end{array}$ \\
\hline
\end{tabular}

Under the current state of management, there are situations of mutual duplication of functions, and sometimes even conflicts over the division of powers between different executive bodies. In result their actions are inadequately organized and coordinated that drastic cally reduces the effectiveness of the state water objects management. For example, the task of surface water state regular monitoring conducting is responsibility both of State Agency of Water Resources and of the State Service of Ukraine for Emergency Situations, but the generalized accounting of hydrometric and hydrochemical observations is carried out only by the last agency. At the same time, the State Agency of Water Resources has much wider analytical base (more observation 
points, a wider list of indicators under analysis), consequently the results are more accurate and detailed. In our opinion, the transfer of powers to monitor the surface water bodies state and the generalization of the results from the State Service of Ukraine for Emergency Situations to the State Agency for Water Supply would be a rational and expedient decision. In addition, each authorized executive body keeps records of water objects, in accordance with current legislation, in their own registration system (Fig.1).

Note that only the State Land Cadastre is a truly automated geographic information system operating in the entire territory of Ukraine and the information of which is accessible for viewing on a public geoportal. The cityplanning cadastre is automated only within the Kyiv city. The rest of the information (or registration) systems are tabular databases without geospatial bindings. In this regard, the State Land Cadastre was chosen as the platform for implementation of the interdepartmental project "Water Resources Geoportal", which is currently in the process of development.
Today, the State Water Cadastre exists in the form of three separate sections. It includes the state registers of waters which are provided by three different executive bodies: "Water Use" (State Agency of Water Resources of Ukraine), "Surface Water" (State Service of Ukraine for Emergency Situations) and "Groundwater" (State Service of Geology and Subsoil of Ukraine). The State Water Cadastre is a tool for systematization of state water data and the definition of water resources available for use [2].

Information about the land plots of the water fund is contained in the State Land Cadastre and comes to it from the State Service of Ukraine for Emergency Situations in accordance with the procedure for information interaction between inventories and information systems [15]. In addition, the State Land Cadastre receives information on restrictions on land use from the State Service of Geology and Subsoil of Ukraine. The State Agency of Water Resources of Ukraine transfers the information about the water resources use, the activities of design, construction and reconstruction of protection systems against harmful

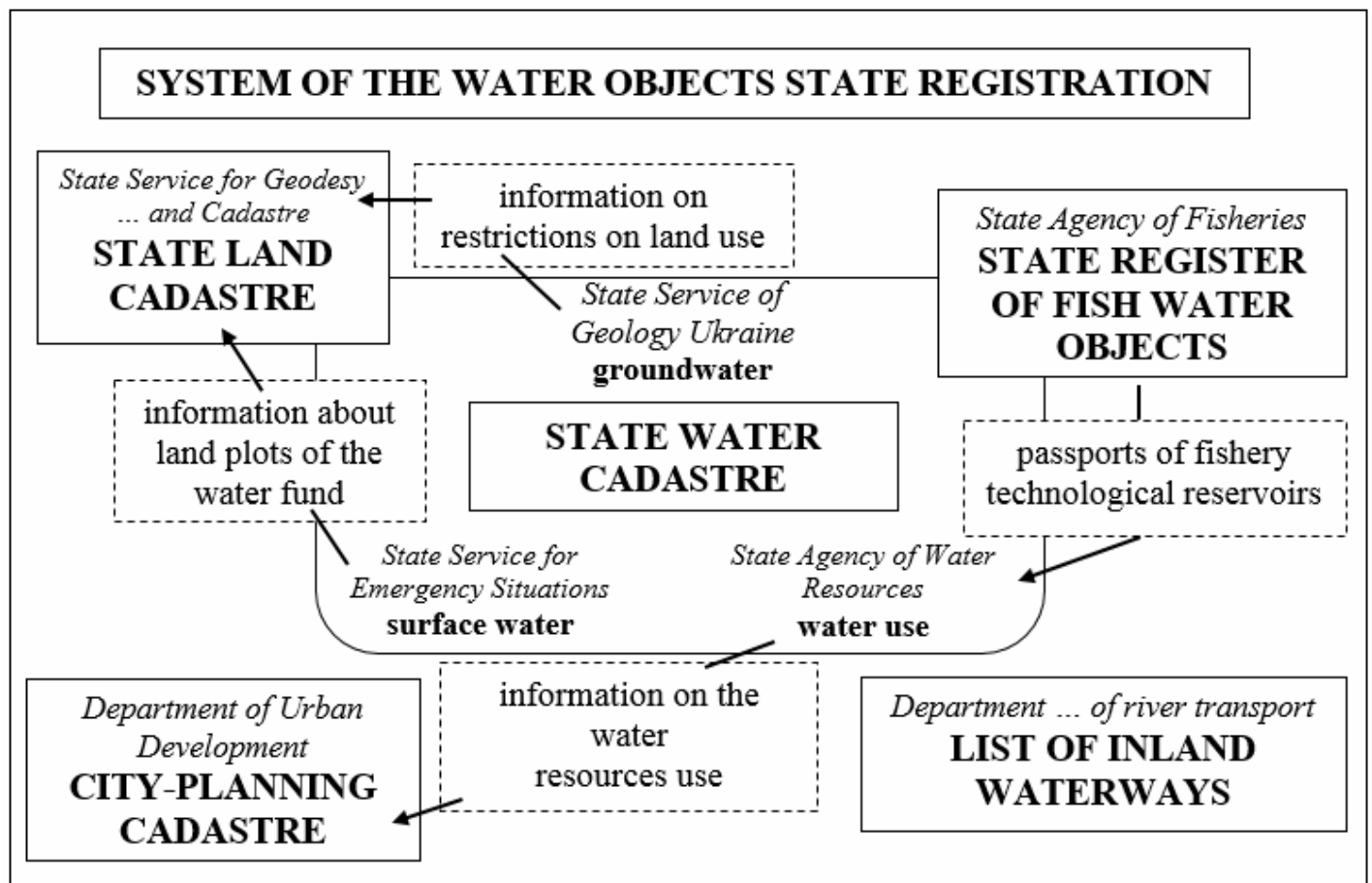

Fig.1. System of the water objects state registration (according to the current legislation) 
effects of water, water management objects of multipurpose use, so on to the city-planning cadastre [16]. Detailed information on fishing technological reservoirs is sent to the State Agency of Water Resources of Ukraine in the form of Passports, copies of which are saved in paper form in the basin or regional water resources administrations, dependently from the location of the reservoir [17, p.3.1]. The list of inland waterways [18], which also has a textual view, is not related to any other data set. In addition, none of the existing account systems implies the availability of any analytical tools for making managerial decisions regarding water objects.

Taking into account the lack of published official materials of the State Water Cadastre, we have sent requests for public information to the authorities, managing it (the State Agency of Water Resources of Ukraine, the State Service of Ukraine for Emergency Situations, the State Service of Geology and Subsoil of Ukraine) in order to assess the actual state of water objects accounting in Ukraine. The results are given in Table 3 .

Table 3. Results of responses analysis to information requests

\begin{tabular}{|l|l|l|}
\hline $\begin{array}{c}\text { State Agen- } \\
\text { cy of Water } \\
\text { Resources } \\
\text { of Ukraine } \\
\text { ("Water } \\
\text { Use") }\end{array}$ & $\begin{array}{c}\text { State Service of } \\
\text { Geology and } \\
\text { Subsoil of } \\
\text { Ukraine } \\
\text { ("Groundwa- } \\
\text { ter") }\end{array}$ & $\begin{array}{c}\text { State Service } \\
\text { of Ukraine for } \\
\text { Emergency } \\
\text { Situations } \\
\text { ("Surface } \\
\text { Water") }\end{array}$ \\
\hline State Water Cadastre system automation degree \\
\hline $\begin{array}{l}\text { Data is sys- } \\
\text { tematized } \\
\text { using spe- } \\
\text { cialized } \\
\text { software }\end{array}$ & $\begin{array}{l}\text { Automated } \\
\text { State Water } \\
\text { Cadastre infor- } \\
\text { mation system } \\
\text { ("Groundwa- } \\
\text { ter") is created } \\
\text { in the ORACLE } \\
\text { environment }\end{array}$ & $\begin{array}{l}\text { There is no } \\
\text { automated } \\
\text { State Water } \\
\text { Cadastre in- } \\
\text { formation } \\
\text { system }\end{array}$ \\
\hline \multicolumn{3}{|c|}{ Information in the State Water Cadastre } \\
\hline $\begin{array}{l}\text { Data on } \\
\text { water col- } \\
\text { lection, use, } \\
\text { discharge } \\
\text { and purifi- } \\
\text { cation }\end{array}$ & $\begin{array}{l}\text { 19 databases } \\
\text { containing data } \\
\text { on groundwater }\end{array}$ & $\begin{array}{l}\text { Data of hy- } \\
\text { drometric and } \\
\text { hydrochemical } \\
\text { observations }\end{array}$ \\
\hline
\end{tabular}

\begin{tabular}{|c|c|c|}
\hline \multicolumn{3}{|c|}{ Basic accounting units } \\
\hline $\begin{array}{l}\text { Water man- } \\
\text { agement } \\
\text { areas for } \\
\text { each river } \\
\text { basin }\end{array}$ & $\begin{array}{l}\text { Administrative } \\
\text { areas, hydro- } \\
\text { logical basins } \\
\text { of underground } \\
\text { waters, river } \\
\text { basins, water } \\
\text { supply areas } \\
\text { and throughout } \\
\text { Ukraine }\end{array}$ & $\begin{array}{l}\text { River crea- } \\
\text { tions and hy- } \\
\text { drological } \\
\text { posts }\end{array}$ \\
\hline \multicolumn{3}{|c|}{$\begin{array}{c}\text { Ways of promulgation State Water Cadastre } \\
\text { information }\end{array}$} \\
\hline $\begin{array}{l}\text { Yearbooks } \\
\text { in paper } \\
\text { form. It is } \\
\text { planned to } \\
\text { publish data } \\
\text { on the State } \\
\text { Agency of } \\
\text { Water Re- } \\
\text { sources } \\
\text { website }\end{array}$ & $\begin{array}{l}\text { Annual Edition } \\
\text { of Groundwater } \\
\text { State Balances } \\
\text { (Paper). Inter- } \\
\text { active map } \\
\text { "Mineral depos- } \\
\text { its" }\end{array}$ & $\begin{array}{l}\text { Annual and } \\
\text { perennial pa- } \\
\text { per editions of } \\
\text { the Central } \\
\text { Geophysical } \\
\text { Observatory. } \\
\text { Generalized } \\
\text { information } \\
\text { on the website } \\
\text { of the CGO }\end{array}$ \\
\hline \multicolumn{3}{|c|}{$\begin{array}{l}\text { Ways to get acquainted with State } \\
\text { Water Cadastre data }\end{array}$} \\
\hline $\begin{array}{l}\text { With year- } \\
\text { books - in } \\
\text { State Agen- } \\
\text { cy of Water } \\
\text { Resources }\end{array}$ & $\begin{array}{l}\text { With balances - } \\
\text { in reading } \\
\text { room; with } \\
\text { interactive map } \\
\text { - on the website } \\
\text { of SSPE } \\
\text { "Geoinform } \\
\text { Ukraine" }\end{array}$ & $\begin{array}{l}\text { With the pub- } \\
\text { lications of } \\
\text { CGO - in the } \\
\text { branch obser- } \\
\text { vations ar- } \\
\text { chive of the } \\
\text { CSO. With } \\
\text { generalized } \\
\text { data - on the } \\
\text { site of CGO }\end{array}$ \\
\hline \multicolumn{3}{|c|}{$\begin{array}{c}\text { Ability to obtain information from the State } \\
\text { Water Cadastre about a water object in the form } \\
\text { of an official document }\end{array}$} \\
\hline $\begin{array}{l}\text { The proce- } \\
\text { dure for } \\
\text { State Water } \\
\text { Cadastre } \\
\text { conducting } \\
\text { does not } \\
\text { provide } \\
\text { information } \\
\text { about a } \\
\text { water object } \\
\text { in the form } \\
\text { of an ex- } \\
\text { tract, a cer- } \\
\text { tificate, any } \\
\text { other offi- } \\
\text { cial docu- } \\
\text { ment }\end{array}$ & $\begin{array}{l}\text { Information } \\
\text { from the State } \\
\text { Water Cadastre } \\
\text { is provided in } \\
\text { the form of } \\
\text { source docu- } \\
\text { ments and cer- } \\
\text { tificates if } \\
\text { available in the } \\
\text { database }\end{array}$ & $\begin{array}{l}\text { Information in } \\
\text { the form of } \\
\text { ballots, re- } \\
\text { views, maps, } \\
\text { certificates is } \\
\text { provided on a } \\
\text { contractual } \\
\text { basis }\end{array}$ \\
\hline
\end{tabular}


As a result, it can be argued that the existing State Water Cadastre in Ukraine does not fully comply with art.28 of the Water Code of Ukraine [2, art.28], because it does not properly perform the functions of systematizing the State Water Cadastre data and determining the water resources available for use. The State Water Cadastre is conducted by different units using different methods, and its data are in no way connected and corresponded with each other. The order of information interaction between inventories and information systems is practically not carried out, as the sections "Water use" and "Surface water" are not automated, and Automated State Water Cadastre information system ("Groundwater") technically and informatively has no connection with the State Land Cadastre. Promulgation of the state water accounting data is carried out in paper form, and the information is closed and is available for inspection only within the organizations that create it. In addition, in our opinion, there is no unified mechanism for obtaining information from the State Water Cadastre about a water object (which legislatively is a public information category) in the form of an extract, a certificate or other official document. For example: the State Service of Geology and Subsoil of Ukraine reaffirm the consent to provide information in the form of source documents and certificates if it is available in the database; the Central Geophysical Observatory (department of the State Service of Ukraine for Emergency Situations, authorized to conduct surface waters state accounting) offers to receive information on a contractual basis; the State Agency of Water Resources of Ukraine in general refuses to provide information on water objects in the form of an official document, arguing that such a mechanism for its receipt is not provided for in the Procedure for the State Water Cadastre. The result is the lack of an information field for management and investment decisions on water objects [19].

Since water objects are three-dimensional (they contain a certain amount of water, have a unique relief of the bottom), their recording in existing two-dimensional cadastral systems in principle cannot be complete and adequate due to the impossibility of evaluating the object's properties. A number of managerial issues arising from the use of water bodies cannot be reasonably solved without the possession of three-dimensional information about a water object [20].

\section{CONCLUSIONS}

Analyzing production and management experience, it can be argued that the existence of a three-dimensional system for water objects monitoring and accounting (3D cadastre) will significantly improve the efficiency of the use of resources associated with water objects, and may be a government management instrument.

Differences in the approaches of Ukrainian and European legislation and the science of hydrology to the water objects classification lead to the fact that the resulting classification systems cannot be compared with each other. The inevitable consequence of this situation will be the complexity of integrating Ukrainian geospatial data on water objects into the European Infrastructure for Spatial Information in the European Community (INSPIRE) [21]. In view of this, it is necessary not only to supplement the list of water objects in accordance with the Water Code of Ukraine, including swamps in view of their important role in ecosystems, but also to develop a methodological approach of the conversion and adaptations of the domestic water objects classification in Ukraine with the European classification.

The dispersal of information on water bodies by various departments and the lack of unification of this information makes it impossible to unite it into a single system with further transformation and integration into international information systems [22]. The result is the lack of an information field for making managerial decisions regarding water bodies.

The peculiarities of water objects cadastral accounting in Ukraine testify to the urgent need to create a single, three-dimensional monitoring and accounting system for water objects, with data and analytical functions open to stakeholders, in order to increase the efficiency of public administration. Implementation of this task requires the following steps: 
1. Optimization and harmonization of the current legislation provisions on the water objects management, excluding cases of mutual duplication of functions by various executive authorities.

2. Simplifying access to existing data of the State Water Cadastre by publishing them on official web sites of cadastre management subjects - since such data relate to public information and access to them cannot be limited.

3. Formulation the task of designing a single three-dimensional cadastral system for the water objects registration at the state level and development of a methodology for the water objects registration in a three-dimensional space.

\section{REFERENCES}

1. Rudenko I., 2015. Current situation of water supply in Ukraine. http://waternet.ua/news/ newsletter/158/ (in Russian).

2. Water Code of Ukraine, 1995. Law, Code of Ukraine, No213/95-VR. http://zakon3.rada. gov.ua /laws/ show/213/95-\%D0\%B2\%D1\%80 (in Ukrainian).

3. Law of Ukraine On the State Border of Ukraine, 1991. No. 1777-XII. http://zakon3. rada.gov.ua/laws/show/1777-12 (in Ukrainian).

4. Khilchevsky V.K. and others, 2008. General Hydrology: Textbook. Publishing and Printing Center Kyiv University, Kyiv, 399 (in Ukrainian).

5. Water Framework Directive 2000/60/EC, 2000.

6. Stepanets K., 2015. Encyclopedia of Kiev rivers. Anthology of the forgotten reservoirs of the city, $2^{\text {nd }}$ edition, 248 (in Russian).

7. GOST 19185-73. Hydrotechnics. Basic concepts. Terms and Definitions. http://docs.cntd. ru/document/gost-19185-73 (in Russian).

8. Dmitriev A.F. and others, 1999. Hydrotechnical structures: Textbook for universities, 328 (in Ukrainian).

9. Land Code of Ukraine, 2001. Law, Code of Ukraine, No 2768-III. http://zakon2.rada.gov.ua /laws/show/2768-14 (in Ukrainian).

10.Law of Ukraine About transport, 1994. No.232/94-VR. http://zakon3.rada.gov.ua/laws/ show/232/94-\%D0\%B2\%D1\%80 (in Ukrainian).

11.City Information and Analytical System for Urban Development Activity Kyiv City Plan- ning Cadastre, 2017. http://mkk.kga.gov.ua/ (in Ukrainian).

12. Resolution of the Cabinet of Ministers of Ukraine On the legal regime of zones of sanitary protection of water objects, 1998. No.2024. http://zakon2.rada.gov.ua/laws/show/ 2024-98$\% \mathrm{D} 0 \% \mathrm{BF}$ (in Ukrainian).

13.Snezhko I.I., 2014. Method of calculating the constructing models accuracy of real estate objects in the 3D cadastre. PhD Thesis, 25.00.26, 140 (in Russian).

14.Stoter J.E., 2004. 3D Cadastre: PhD Thesis. Publications on Geodesy 57. Delft, NCG, 327.

15. Resolution of the Cabinet of Ministers of Ukraine On Approval of the Procedure for Information Interaction Between Inventories and Information Systems, 2013. No.483. http://zakon3.rada.gov.ua/laws/show/483-2013$\% \mathrm{D} 0 \% \mathrm{BF}$ (in Ukrainian).

16. Resolution of the Cabinet of Ministers of Ukraine About city planning cadastre, 2011. No. 559. http://zakon2.rada.gov.ua/laws/show/ 559-2011-\%D0\%BF (in Ukrainian).

17.Order of the Ministry of Agrarian Policy of Ukraine On Approval of the Procedure for the Development of the Fishery Water Reservoir Passport, 2013. No.742. http://zakon2.rada. gov.ua/laws/show/z0027-14 (in Ukrainian).

18. Resolution of the Cabinet of Ministers of Ukraine On approval of the list of inland waterways belonging to the navigable category, 1996. No.640. http://zakon3.rada.gov.ua/ laws/show/640-96-\%D0\%BF (in Ukrainian).

19.Petrakovska O. and others, 2013. Classification of European Land Cadaster Systems according to Legal Families, Modern achievements of geodesic science and production: Collection of scientific works, No.1(25), 2013, 118-123 (in Ukrainian).

20.Dubnytska M. and others, 2017. New Approaches to Water Bodies Account and Monitoring (Three-dimensional Space). Urban planning and territorial planning, Collection technical and scientific works, No.64, 2017, 70-79 (in Ukrainian).

21.Ustinova I., 2015. Theoretical principles of wave urbanistics. Underwater Technologies, Vol.01, 33-42.

22.Zatserkovnyi V. and others, 2017. Geoportal as a means to popularize geological heritage of Ukraine. Underwater Technologies, Vol.07, 1827. 


\section{Особенности кадастрового учёта и мониторинга водных объектов в Украине}

\section{Ольга Петраковская, Маргарита Дубниикая}

Аннотация. Представлены особенности и проблемы кадастрового учета водных объектов в Украине. Изложены результаты анализа нормативно-правовой базы в области мониторинга водных ресурсов и их учета в кадастре. Авторы сравнивают подходы к классификации водных объектов, принятые в украинском и европейском законодательстве, а также в науке гидрологии. Приведен перечень существующих типов водных объектов с определениями с точки зрения кадастрового учёта. Рассмотрена классификация кадастровых систем в зависимости от их размерности, то есть способности отображать объект реального мира в определенном количестве пространственно-временных измерений.

Проанализирована государственная система управления водными ресурсами в Украине и распределение обязанностей между органами исполнительной власти. Выявлены некоторые проблемы, такие как многократное дублирование функций, а иногда - даже конфликты по поводу распределения полномочий между различными исполнительными органами. Формализована система государственной регистрации водных объектов в Украине в соответствии с действующим законодательством. В частности, детально проанализированы системы учета водных объектов в Украине.
Авторами направлены запросы на публичную информацию в органы власти, осуществляющие ведение государственного водного кадастра в Украине (Государственное агентство водных ресурсов Украины, Государственная служба Украины по чрезвычайным ситуациям, Государственная служба геологии и недропользования Украины). На основе анализа ответов проанализировано состояние Государственного водного кадастра в Украине и оценена его способность выполнять управленческие задачи. Доказано, что учет водных объектов в существующих двухмерных кадастровых системах в принципе не может быть полным и адекватным, поскольку водные объекты являются трехмерными по своей природе. Рекомендовано разработать единую трехмерную систему мониторинга и учета водных объектов в Украине.

Ключевые слова: водные объекты, управленческие решения, трехмерный кадастр, классификация, Государственный водный кадастр. 